\title{
Maxillary odontogenic keratocyst: a clinical case report
}

\author{
Ceratocisto odontogênico maxilar: relato de caso clínico
}

Daniel Antunes FREITAS 1

Daniela Araújo VELOSO'

Alisson Luís D'Afonseca SANTOS'

Vinícius Antunes FREITAS²

\begin{abstract}
Odontogenic keratocysts are benign lesions of the maxillomandibular region with high growth potential resulting in huge bone destruction. The presence of multiple Odontogenic keratocysts can be associated with the Gorlin-Goltz syndrome. There are two accepted theories of their origin: remnants of dental lamina and proliferation of cells from the basal layer of oral epithelium into the mandible or maxilla. Odontogenic keratocysts are usually asymptomatic and are diagnosed incidentally on routine periapical or panoramic radiographs. The type of treatment is related to their high recurrence rate. The objective of the present study is to report a clinical case of a surgical treatment of a parakeratinized odontogenic keratocyst by enucleation in a fourteen-year old girl. This technique was used since the complete removal of the cyst posed no risks of complications from a dental and/or anatomical point of view. Furthermore, it facilitated the comprehensive anatomohistopathological analysis of the lesion including its clinical, histopathological, and radiological aspects.
\end{abstract}

Indexing terms: Basal cell nevus syndrome. Maxilla. Odontogenic cysts.

\section{RESUMO}

Os ceratocistos odontogênicos são apresentados como lesões benignas do complexo maxilomandibular, de grande potencial de crescimento e de grande destruiçäo óssea podendo, quando em múltiplas apresentações, serem associados à "Síndrome de Gorlin", existindo, para tanto, duas teorias para o seu desenvolvimento: uma delas a partir de remanescentes da lâmina dentária, e outra a partir da proliferação de células da camada basal ou do epitélio oral para a mandíbula ou maxila. Os ceratocistos odontogênicos são lesões de caráter geralmente assintomáticos, sendo comumente descobertos em exames radiográficos panorâmicos ou periapicais de rotina. Suas formas de tratamento estão relacionadas ao seu grande potencial recidivante. O presente trabalho tem como objetivo o relato de caso clínico de uma jovem de quatorze anos de idade, em que um ceratocisto odontogênico paraqueratinizado na maxila foi retirado cirurgicamente por enucleação. Tal técnica foi escolhida uma vez que a retirada completa do cisto em questão não representava complicações dos pontos de vista dental e/ou anatômico; e facilitava o estudo integral da lesão com relação ao exame anatomohistopatológico, analisando ainda seus aspectos clínicos, histopatológicos e radiográficos.

Termos de indexação: Síndrome do nevo basocelular. Maxila. Cistos odontogênicos.

\section{INTRODUCTION}

Reclassified in 2005 by the World Health Organization as a benign tumor, odontogenic keratocyst is an intraosseous lesion of the maxilla with a destructive and invasive behavior, high recurrence rate (25\% to $62.5 \%)$, and specific histological aspects'.

Although first described in 1956', its etiopathogenesis is not yet entirely clear; there are two accepted theories of their origin: remnants of dental lamina and proliferation of cells from the basal layer of oral epithelium into the mandible or maxilla ${ }^{3}$. Due to the fact it develops before the formation of the crown of the tooth, it was previously known as primordial cyst ${ }^{4}$.

Odontogenic keratocysts are asymptomatic lesions, but occasionally, in severe cases, some symptoms such as swelling, drainage, or pain can be shown ${ }^{5}$. Small odontogenic keratocysts, usually asymptomatic, are often discovered only during radiographic examination $n^{4,6}$ and may also be associated with basal cell nevus syndrome, also known as Gorlin-Goltz syndrome ${ }^{4,7-9}$.

According to $\mathrm{Chow}^{10}$, in the mandible, this lesion tends to grow in an anteroposterior direction within the medullary cavity of the bone, without causing obvious

\footnotetext{
${ }^{1}$ Faculdades Unidas do Norte de Minas. Av. Osmane Barbosa, 11111, Conjunto Residencial JK, 39404-006, Montes Claros, MG, Brasil. Correspondência para / Correspondence to: DA FREITAS.E-mail: <danielmestradounincor@yahoo.com.br>.

2 Santa Casa de Misericórdia de Belo Horizonte. Belo Horizonte, MG, Brasil.
} 
bone expansion resulting in its delayed observation ${ }^{5}$. In the jaw, since it is a less compact bone and due to the proximity to the maxillary sinus, the lesion tends to grow spherically, and thus it can be observed in its early stages of formation.

OKCs can occur over a wide age range, varying from the first to the ninth decade of life. Its peak incidence is during the second and third decades of life, and it is more frequently found in males than in females, with a male-to-female ratio of 1.5 .

These lesions can be seen radiographically using intraoral and panoramic imaging techniques, which, although having some limitations, are important diagnostic tools for detecting OKCs. On the other hand, computed tomography allows for the accurate assessment of the true extent of the lesion and its relationship to important anatomic structures, contributing to surgical planning ${ }^{11-12}$. Radiological examination shows lesions with unilocular or multilocular appearance due to their size. However, the majority of radiological results display well-defined unilocular radiolucent lesions that are associated with the crown of a tooth, which may raise doubts about their diagnosis.

Multilocular cysts that resemble ameloblastoma are common, especially in the jaw. This fact can be useful in the clinical and radiographic differential diagnosis since the large radicular and dentigerous cysts are commonly associated with expansion of the bone ${ }^{12-13}$. The odontogenic keratocyst has a thin, friable capsule rich in polysaccharides and that lacks inflammatory cell infiltrate; it is often difficult to enucleate from the bone. The cystic lumen may contain a clear fluid that is similar to the plasma transudate, or it may be filled with a cheesy material which, on microscopic examination, consists of keratinaceous debris ${ }^{4,7}$.

Histopathologically, the cystic epithelium is either parakeratinized ( $80 \%$ of cases) or orthokeratinized $(20 \%)$; it is uniform and is usually 5-8 cell layers thick containing basophilic nuclei (H\&E staining) with palisaded basal layer with a flat epithelial-mesenchymal junction.

According to Blanas et al. ${ }^{14}$, different surgical techniques are used to treat keratocysts depending on their size and the affected region. There is a variety of surgical treatments to choose from including curettage or even mandibular or maxillary resection.

Among the techniques associated with high recurrence rate are enucleation, curettage, and marsupialization since there may be remaining lesion tissues left behind in the affected area. The odontogenic keratocyst, especially the parakeratinized type, is one of best-known jaw cysts for its aggressive behavior and high recurrence rate.

Upon confirmation of an odontogenic keratocyst diagnosis, the Gorlin-Goltz syndrome should be suspected and investigated. In addition to having this type of cyst, most individuals with this syndrome have basal cell carcinomas and skeletal anomalies, $5^{5-18}$.

Therefore, the objective of the present study is to report a clinical case of parakeratinized odontogenic keratocyst addressing its clinical, radiographic, and histological aspects, focusing on contributing to a better understanding of the characteristics and the biological behavior of this type of odontogenic cyst due to its likelihood of misdiagnosis ${ }^{1,6-7,13,15}$.

\section{CASE REPORT}

A 14-year old female patient with leucoderma sought orthodontic treatment at a specialized dental care service and underwent routine panoramic and periapical radiographs, which showed a mild bone loss near the root of the maxillary left canine ( tooth \# 23) (Figure 1).

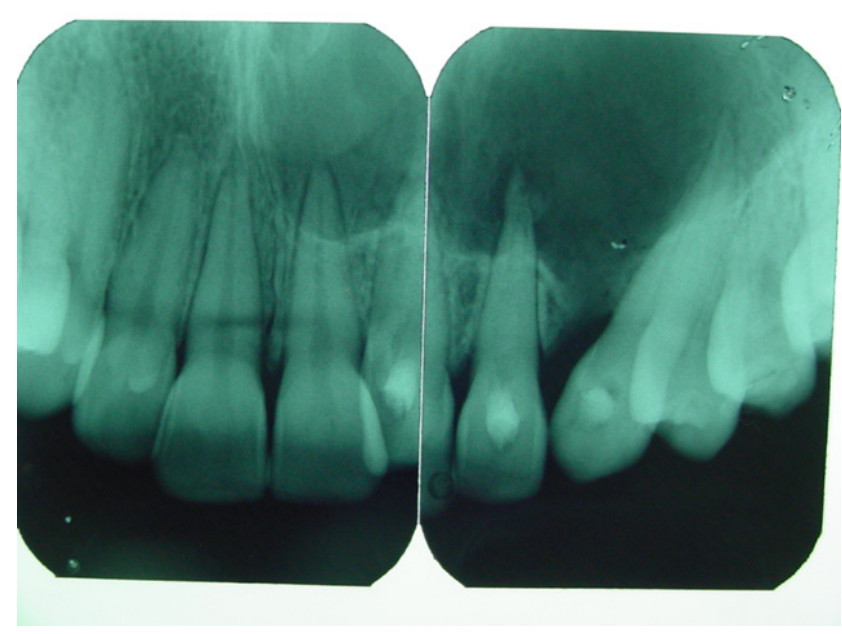

Figure 1. Periapical radiographs showing the lesion.

A periapical cyst was suspected, and the patient was referred to an endodontist for endodontic treatment in teeth \#21,\#22, and \#23 due to the radiolucent lesion seen surrounding the roots of these three teeth (Figure 2). 


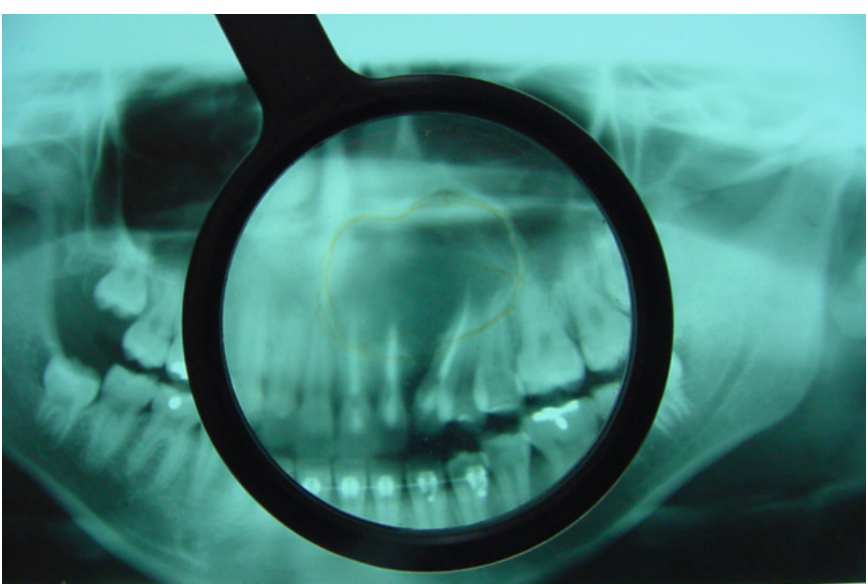

Figure 2. Panoramic radiograph shows the lesion size.

After a two-month treatment, the patient returned to the orthodontist with a major swelling of the left side of the face. The patient was then referred to us and underwent a panoramic radiography and computed tomography. The panoramic radiograph showed a large radiolucent lesion extending from the midline to the left first molar. Computed tomography confirmed the massive growth of the lesion in the vestibular-palatal direction (Figure 3).

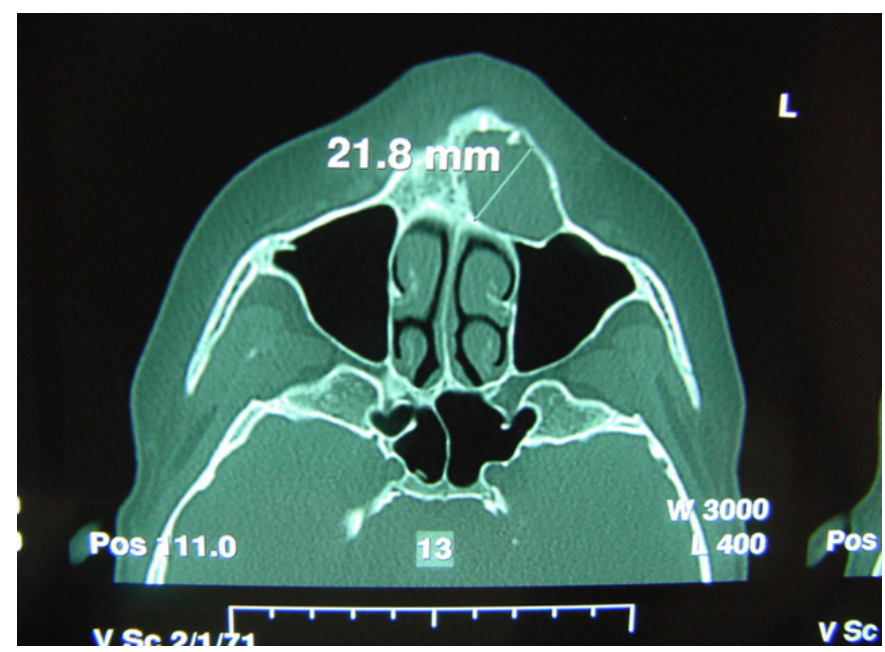

Figure 3. Computed tomography showing the vestibular-palatal extent of the lesion.

The diagnostic hypotheses included fibromyxoma, osteosarcoma, and ameloblastoma. The lesion was enucleated and sent for histopathological examination, which confirmed the diagnosis of parakeratinized odontogenic keratocyst (Figure 4).

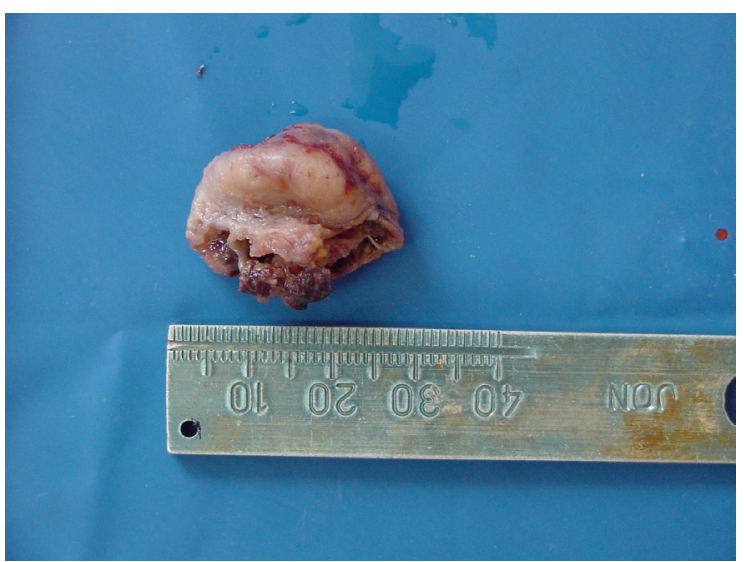

Figure 4. Removed lesion

Microscopically, the histological sections stained with hematoxylin and eosin showed fragments of an odontogenic cystic lesion lined by stratified squamous epithelium with flat basal cells and a parakeratinized surface. The capsule was made up of fibrous connective tissue, mostly collagenous, moderately cellularized with fusiform fibroblasts. A moderate inflammatory infiltrate was also observed. The patient has been followed-up, and the postoperative care and assessment have indicated that the surgery was highly successful.

\section{DISCUSSION}

Developmental odontogenic cysts arise from epithelial remnants of the different stages of odontogenesis, whose pathogenesis is not associated with inflammatory stimuli. They include seven different lesions, and the two most common cysts are the dentigerous cyst and the keratinizing odontogenic cyst, also known as Keratocyst ${ }^{19}$.

The case study presented here confirms the literature data since the lesion, although invasive, was painless and did not affect adjacent dental elements. Most cysts in this group of lesions have a benign course with slow and asymptomatic growth. However, odontogenic keratocysts originating from remnants of the dental lamina have an aggressive clinical behavior and a high recurrence rate, unlike the other odontogenic cysts ${ }^{19}$.

The anatomopathological examination results confirmed a keratocyst, based on its characteristics of epidermoid cyst with hyaline cartilage. This type of cyst usually contains parakeratin ${ }^{17}$, which was also found in this case. Panoramic radiograph proved very important for the discovery and study of intraosseous lesions that affect the bones of the maxillomandibular complex and an effective 
method of postoperative follow-up. A radiolucent area attached to a dental element is very common in cases of odontogenic keratocyst ${ }^{18}$.

These cysts can be treated by two different techniques: marsupialization and enucleation. Marsupialization relieves pressure within the cyst through the opening maintaining continuity between the cyst and the oral cavity. On the other hand, enucleation results in low recurrence rates results, enables faster bone healing, and has shorter healing time $\mathrm{e}^{20-22}$.

Based on the studies aforementioned, since the lesion had not affected any important anatomical structure and its removal would not pose aesthetic and/or functional risks ${ }^{14}$, enucleation was the technique chosen because of its success in preventing recurrences of this type of pathology.

Nevertheless, itisworthmentioning thatenucleation should not necessarily be used in all cases. In some cases, Marsupialization should be used instead, especially when the lesion affects the roots of functionally important teeth and different anatomical elements ${ }^{21}$. In the case presented

\section{REFERENCES}

1. Meara JG, Shah SS, Li KK, Cunnigham M. The odontogenic keratocyst: a 20-year clinicopathologic review. Laryngoscope. $1998 ; 108(2): 280-3$

2. Philipsen HP. Om keratocyster (kolesteatom) । kaeberbe Tandlaegebladet. 1956;60:963-80

3. Forssel $\mathrm{K}$, Forssel $\mathrm{H}$, Kahnberg. Recurrences of keratocysts in a long term follow-up study. Int J Oral Maxillofac Surg. 1988;17(1):25-8.

4. Kramer IRH, Pindborg JJ, Histological typing of odontogenic tumors. 2 ed. Geneva: Whord Health Organization; 1992.

5. Shear M. Cistos da região bucomaxilofacial: diagnóstico e tratamento. $3^{\text {a }}$ ed. São Paulo: Santos; 1999.

6. Marzella ML, Poon CY, Peck R. Odontogenic keratocyst of the maxilla presenting as periodontal abscess. Singapore Dent J. 2000;23(Suppl 1):45-8.

7. Cawson RA, Binnie WH, Eveson JW. Atlas colorido de enfermidades da boca. Correlações clínicas e patológicas. $2^{a}$ ed. São Paulo: Artes Médicas; 1997.

8. Barreto DC, Chimenos EK. New considerationsabout the diagnosis of odontogenic keratocyst. Med Oral. 2001;6(5):350-7.

9. Reichart PA, Philipsen HP. Patologia bucal. Porto Alegre: Artmed; 2000

10. Chow HT. Odontogenic keratocyst: a clinical experience in Singapore. Oral Surg Oral Med Oral Pathol Oral Radiol Endod. 1998;86(5):573-7. here, enucleation was chosen since the complete removal of the cyst posed no risks of complications from a dental and/or anatomical point of view and facilitated the comprehensive anatomohistopathological analysis of the lesion.

\section{CONCLUSION}

Despite its aggressive behavior and high recurrence rate, the etiopathogenesis of the odontogenic keratocyst is not fully understood. Therefore, there is a need for further studies to better understand its characteristics for more accurate diagnosis and for the development and adoption of less aggressive therapeutic approaches that are perfectly adequate for each case in order to prevent its recurrence.

\section{Collaborators}

All authors made substantial contributions to all stages of conception and design of this study.

11. Cotti E, Vargiu P, Dettori C, Mallarini G. Computerized tomography in the management and follow-up of extensive periapical lesion. Endod Dent Traumatol. 1999;15(4):186-9.

12. Garlock JA, Pringle GA, Hicks ML. The odontogenic keratocyst: a potential endodontic misdiagnosis. Oral Surg Oral Med Oral Pathol Oral Radiol Endod. 1998;85(4):452-6. doi:10.1016/ S1079-2104(98)90073-7

13. Oliveira MG, Sant'ana Filho M, Rados PV. Quantificação de AgNORs e expressão do PCNA em ceratocisto odontogênico [online] [citado 2010 Set 20]. Disponível em: <http://www.ufrgs. br/odonto/revistaodonto/estudo51.htm>

14. Blanas N, Freund B, Schartz M, Furst I. Systematic review of treatment and prognosis of the odontogenic keratocyst. Oral Surg Oral Med Oral Pathol. 2000,90(5):553-8. doi: 10.1067/ moe.2000.110814

15. Piattelli A, Fioroni M, Rubini C. Differentiation of odontogenic keratocysts from other odontogenic cysts by the expression of bcl-2 immunoreactivity. Oral Oncol. 1998;34(5):404-7. doi: 10.1016/S1368-8375(98)00026-8

16. Myoung $H$, Hong SP, Hong SD, Lee Jl, Lim CY, Choung PH, et al. Odontogenic keratocyst: review of 256 cases for recurrence and clinicopathologic parameters. Oral Surg Oral Med Oral Pathol Oral Radiol Endod. 2001;91(3):328-33. doi: 10.1067/ moe.2001.113109

20. Israel MS, Braga LC, Dias EP. Ceratocisto odontogênico: revisão de literatura e relato de caso. Rev Bras Patol Oral. 2005;4(3):5969

21. Lustmann J, Bodner L. Dentigerous cysts associated with supernumerary teeth. Int J Oral Maxillofac Surg. 1988;17(2):1002. 
22. Maxymiw WG, Wood RE. Carcinoma arising in a dentigerous cyst: a case report and review of the literature. J Oral Maxillofac Surg. 1991;49(6):639-43. doi:10.1016/0278-2391(91)90347-0
Received on: 13/10/2014 Final version resubmitted on: 19/2/2015 Approved on: 31/3/2015 